\title{
PAPERS OF SELECTED NEW JERSEY POLITICIANS: A SUMMARY GUIDE
}

\author{
BY KEVIN MULROY
}

AND ALBERT C. KING

Dr. Mulroy is currently an archivist at the Getty Center, Santa Monica, California; Mr. King is Manuscripts Librarian in Rutgers University Special Collections and Archives.

\begin{abstract}
$\mathrm{O}$ NLY those papers of New Jersey politicians who served as N.J. Governor, U.S. Representative and/or U.S. Senator have been examined for inclusion in this guide. The 22 entries here presented describe only those manuscript collections from the targeted category which, in the compilers' view, include significant documentation of an individual's governmental or political activities. Biographical information is limited to service in the New Jersey legislature, U.S. Congress, or as New Jersey Governor.
\end{abstract}

BRADY, NICHOLAS F., I930-

Congressional papers, 1982 .

I 8.4 cubic $\mathrm{ft}$.

U.S. Senator, 1982. Republican.

Legislative working files; committee subjects files; New Jersey special projects files; legislative and special projects correspondence; general correspondence, including robo letters; co-signed letters; announcements and notices received; speeches and statements; press releases; press clippings; and Newark office files.

CASE, CLIFFORD P., I 904-I 982.

Congressional papers, I934-1982.

ca. 3 I 5 cubic ft.

Member New Jersey Assembly, I 943-I 944; U.S. Representative, I 945-I 953; U.S. Senator, I 95 5-I 979 . Republican.

Biographical files, I 949-1972; daily schedules, I 955-1978; visitors' registers, I 955-I 978; speeches, testimony and published articles, I 947I 977; Congresssional Record remarks, I 955-1976; radio and television transcripts and releases, I954-1978; radio and television recordings, I 945-I 978 , including audio recordings of several of Case's speeches; photographs, 1947-I978; press releases, I945-1978; scrapbooks, I945- 


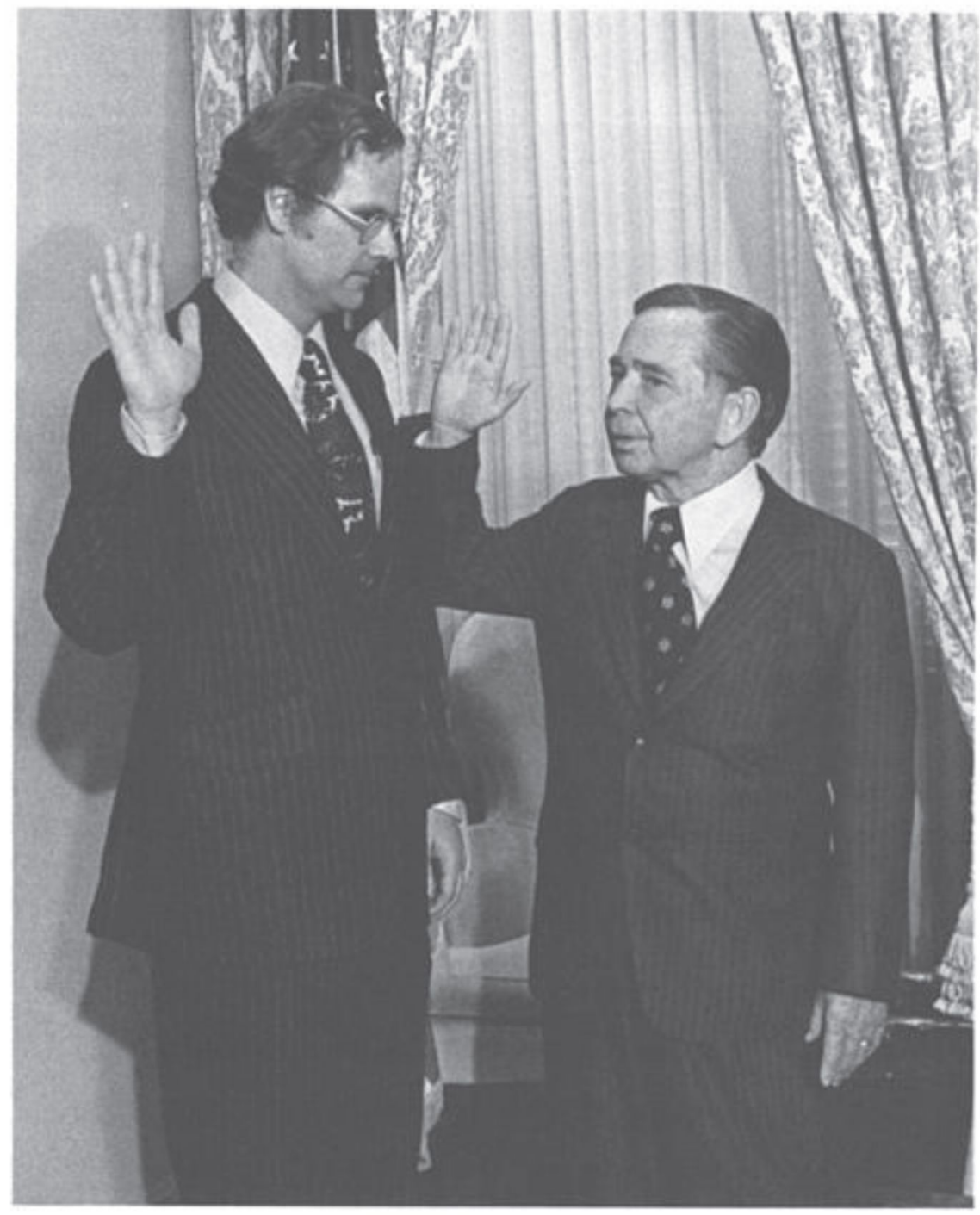

Andrew Maguire and Speaker of the House Carl Albert during Maguire's swearing-in ceremony as a member of the House of Representatives, January I 4, 1975. Maguire, whose Congressional papers are held by Special Collections and Archives, served three terms in Congress from New Jersey's 7 th Congressional District. 
I978; constituent newsletters, I958-1978; white copies, I955-I964, I 97 I, I 976-1978, consisting of selected documents issued each week from Case's office; personal correspondence, I 939- I 98 I, including letters exchanged with Dwight D. Eisenhower, Richard M. Nixon and Lyndon B. Johnson; invitations and contributions, 1955-I 982 ; joint letters, I 9691978; robo letters and enclosures, I955-1978; general correspondence, ca. I 955-1978; legislative correspondence, I944-I953, I955-1960, I976-I978; sponsored and co-sponsored bills, I 945-I 978; legislative working files, ca. I 965-ca. I 978 ; administrative assistant's files, ca. I 959I978; voting record and analysis, I945-1978; academy nominations, I 945-1978; New Jersey projects files, I955-ca. I 978 ; boards and commissions, I934-1982; conference and travel files, I958-1982, including documentation relating to a 1967 trip to Vietnam; political files, I $942-$ I 978 ; editorial cartoons, I 96 I-1 978 ; certificates and awards, I 955-1 978 ; and financial documents, I 943-1952.

Finding aid available in the repository.

CLAWSON, ISAIAH D., I822-I 879.

Letters received, I 855 -I $87 \mathrm{I}$.

. 5 cubic ft.

Member New Jersey Assembly, I 854; U.S. Representative, I 855 I 859 . Whig?

The letters from i 855 to I 860 relate largely to local New Jersey politics in Gloucester, Salem, Cumberland and Cape May counties. Additional letters request public documents or pertain to potential applicants to the U.S. military academies. After I 860 Clawson's correspondence increasingly deals with personal matters, especially finances.

DICKERSON, MAHLON, I $770-1853$.

Papers, I 779-I 857.

.2 cubic $\mathrm{ft}$, , including two microfilm reels.

In part, microfilm of original documents held by The New Jersey Historical Society.

Member, New Jersey Assembly, I 8 I I - 8 I 3 ; New Jersey Governor, I 8 I 5-I 8 I 7; U.S. Senator, I 8 I 7-I 833 . Democrat.

Correspondence, I799-1852; and diary, I809-I8I9. Also papers, I 779-I 784, I 854-I 857 , of other Dickerson family members.

Additional Mahlon Dickerson papers, held on microfilm, consist of diaries, $1782-1809$. 
FENWICK, MILLICENT, i 9 Iо-

Congressional papers, I975-I 982.

ca. 3 Io cubic ft.

Member New Jersey Assembly, I 970-I 972; U.S. Representative, I975-1983; candidate for U.S. Senate, I982. Republican.

Correspondence; administrative files; legislative research files; sponsored and co-sponsored bills; projects files; political and campaign files; financial documents; photographs; press releases; constituent newsletters; and other papers.

Access restricted.

FLORIO, JAMES J., I 937 -

Congressional papers, I975-I98 I.

86 cubic ft.

Member New Jersey Assembly, 1970-1975; U.S. Representative, I $975^{-}$; candidate for New Jersey Governor, 198 I. Democrat.

General and legislative correspondence; special projects files; campaign files; and district office files, including case files and constituent correspondence and requests.

Access restricted.

FORSYTHE, EDWIN B., 1916-1984.

Congressional papers, I $968-1984$.

ca. 200 cubic ft.

New Jersey State Senator, I 964-I 970; Acting New Jersey Governor, I 968 ; U.S. Representative, I 970- I984. Republican.

Legislative working files, I 97 I- I 984 ; committee files, I 97 I-1984, including documentation relating to the Education and Labor Committee, Science and Technology Committee and Merchant Marine and Fisheries Committee; sponsored and co-sponsored bills, I 97 I- I 980 ; federal and departmental agency files, I 97 I-1976; projects files, I 975-I980; co-signed letters, I 977-I980, I 983-I 984; robo letters, I 977-I 984; general and legislative correspondence, I97I-I984; thank-you letters received, I978I 983 ; speeches, statements and Congressional Record remarks, I973-I984; attendance and voting record, I 97 I-I 984; campaign files, I 978; mailing directory, I983; press releases, I974-1984; constituent newsletters, I 975-I 983; press clippings, I 975-I984; and obituaries, tributes and letters of condolence, I 984. Also files, I 968-I 970, relating to the New Jersey State Law Enforcement Planning Agency. 
FRELINGHUYSEN, JOSEPH S., I 869- 948.

Papers, I733-1 948.

ca. 39 cubic ft.

Member New Jersey Senate, I 906-I 9 I 2 ; Acting New Jersey Governor, I909, I910; U.S. Senator, I917-1923. Republican.

Political files, I908-I928, including speeches, campaign literature, subject files and correspondence; speeches and statements, I9I7-I94I; coal and oil files, I920-I926; personal and political scrapbooks, I889I 945; press clippings; correspondence and documents, I 898-I 900, relating to service in the Spanish-American War; papers, I924-1936, concerning Frelinghuysen's Rice Hope Plantation near Charleston, South Carolina; personal correspondence, I 924-1938; and genealogical compilations, notes and other papers relating to the Frelinghuysen family. Also miscellaneous papers, I733-1879, of earlier generations of the Frelinghuysen family.

GREEN, ROBERT S., I 83 I-I 895.

Papers, I $855^{-1} 893$.

.4 cubic ft.

U.S. Representative, I 885-I 887 ; New Jersey Governor, I 887 -I 890. Democrat.

Letters received, I 857 - I 890 , dating chiefly from the period of Green's governorship. Also miscellaneous other papers, I 855-1 893, in part relating to the Washington Inaugural Centennial.

HOWELL, CHARLES R., I 904-I 973.

Congressional papers, I 948-I 955 .

ca. 20 cubic $\mathrm{ft}$.

Member New Jersey Assembly, I 945-1946; U.S. Representative, I 949-1955; candidate for U.S. Senate, 1954. Democrat.

Legislative files; constituent correspondence and invitations; campaign files, I 948-1955, including papers relating to campaign for U.S. Senate; desk diary; audio recordings; press releases; and memorabilia.

\section{MAGUIRE, ANDREW, I 939-}

Congressional papers, I 974-1982.

ca. 35 cubic ft.

U.S. Representative, I 975-198 I. Democrat.

Correspondence, consisting chiefly of robo letters; subject files; sponsored bills; special events and district forums; campaign files and mailing 
lists; appointment books; audio recordings, including campaign spots; photographs; speeches; press releases; constituent newsletters; and newspaper clippings. Also related papers of father Bruce B. Maguire.

MORRIS, LEWIS, I 67 I-I 746.

Papers, I685-1749.

.4 cubic ft.

Forms part of: Robert Morris papers.

Acting New Jersey Governor, I 7 I9-I 720, I 73 I-I732, I 736-I 738; Member, New Jersey Council, I 702-I 705, I 708-1737; Member New Jersey Assembly, I 707-I 708; New Jersey Governor, I 738-I 746.

Governmental, business and other papers, I698-I 749, including letters received, accounts and poetry; legal papers, I 708-I 745; New Jersey Council and Assembly proceedings, I 726, I 740-I 745; and papers relating to Tinton Manor, I685-I 730.

NORTON, MARY T., I875-I 959.

Papers, ca. I 890-I 960.

ca. 4.8 cubic $\mathrm{ft}$.

U.S. Representative, 1925-I95 I. Democrat.

Biographical materials, I926-I959; correspondence, I920-I959, including letters received from Franklin D. Roosevelt, Eleanor Roosevelt and Harry S. Truman; speeches and statements, I923-I 958; writings, I932-1959, including published articles, miscellaneous typescripts and several drafts of Norton's unpublished autobiography; general files, I 9 I 8 I 952; photographs, ca. I 890-I 956, relating both to private and public life; scrapbooks and press clippings, I922-1959; and awards, certificates, degrees and plaques, I 936-I 950. Also letters of condolence, I 959-1 960.

Finding aid available in the repository.

PATERSON, WILLIAM, I745-I806.

Papers, I 756-I 898 .

I. 4 cubic ft. , including four microfilm reels.

In part, microfilm of original documents held by William Paterson College (Wayne, N.J.) and photocopies, with typed transcripts, of original documents held by Princeton University.

Selected William Paterson manuscripts held by Rutgers University Libraries also available on microfilm.

Member New Jersey Council, I 776-1 777; Continental Congress del- 
egate-elect, I 780 , I 787 (declined to serve); U.S. Senator, I 789 -I 790 ; New Jersey Governor, I $790-1793$.

Correspondence and other papers, I766-I8I3; Political essays, ca. I 790 ; legal and judicial documents, ca. I 786-I 804, including notes on points of law, volume of legal forms ["Precedents"], ca. I 786-I 804, receipt book, I770-I 786, New Jersey "Supreme Court Cost Book No. 2," 1777-I790, New Jersey "Supreme Court Docket No. 6," I 788-I790, and letterbook, I 790-I 799, containing also a draft of Peterson's Laws of. the State of New Jersey (published I 800). Also papers, I 787 - I 834, of Paterson's wife Euphemia (consisting chiefly of letters received from Paterson); papers, 1836-I 898, of Paterson's grandson William ( I 8 I 7-I 899); papers, I 763-I 833 , of other family members; and miscellaneous papers lacking an obvious Paterson family connection.

Additional William Paterson papers, held on microfilm, consist of case files, I 765-I803; and dockets, I $78 \mathrm{I}-\mathrm{I} 807$, pertaining to cases before the New Jersey Supreme Court and courts in Hunterdon, Somerset and Middlesex counties. Also East and West Jersey Proprietors' documents, I689ca. I 804, pertaining chiefly to land claims and transactions; Paterson family papers, I760-184 I ; and miscellaneous documents, I 756-I 805 .

Letters of William Paterson ( I745-I 806) indexed in the repository.

PATTEN, EDWARD J., I $905-$

Congressional papers, I963-I 980 .

37 cubic ft.

U.S. Representative, I963-I98 I. Democrat.

Subject correspondence files, I 976-I 980; committee correspondence, I 969-I970, I975-I980; Appropriations Committee files, I973-I980; projects files; Congressional Record remarks, I965-I980; photographs; press releases, I 963-1979; and press clippings.

Access restricted.

Finding aid available in the repository.

PRICE, RODMAN M., I 8 I6-I 894.

Papers, I 838-I 90I.

I. 6 cubic ft.

U.S. Representative, I 85 I-I 853 ; New Jersey Governor, I 8 54- I 857. Democrat.

Correspondence, I 850 - I 893 ; financial documents, I 842 -I 892 , including canceled checks (some as U.S. Navy purser), I $842-$ I 850 , personal 
and household bills and receipts, I 842-I 892, promissory notes of Ward and Price, New York, I $850-1856$, and New Jersey Geological Survey accounts and vouchers, I 854-I 857 ; legal documents, I 838, I 854 -I 872 , relating to the estate of Francis Price (d. I 864); and miscellaneous other papers. Also papers, I 856-I 90I, of various Price family members.

Letters indexed in the repository.

SCHENCK, FERDINAND S., I $790-$ I 860.

Papers, I 73 I-I 879.

5 cubic ft.

Member New Jersey Assembly, I829-I83 I; U.S. Representative, I 833-I 837. Democrat.

Correspondence, I 809- I 860, including letters received from political associates in New Jersey during his Congressional service; papers relating to the New Jersey Assembly, including drafts of bills and reports; political and patriotic speeches; notes on cases heard by Schenck as a New Jersey Court of Errors and Appeals judge; medical notes, formulae and addresses; financial documents, in part relating to Schenck's medical practice, including bills, receipts, accounts, daybooks and ledgers; deeds, mortgages and surveys; and notes, I 846 , on Rutgers College funds. Also papers, I 73 I-I 879, of various family members; and miscellaneous other papers, including Schenck family genealogical notes, clippings and photographs.

Finding aid available in the repository.

SYKES, GEORGE, I 802- I 880.

Papers, I 709-I 879 .

8.4 cubic ft.

U.S. Representative, I 843-I 847; Member New Jersey Assembly, I 877 -I 879 . Democrat.

Political papers, I 836-I 879, consisting chiefly of correspondence relating to Sykes' service in the U.S. Congress and New Jersey Assembly; personal letters received, I 827-I 879; receipts, I 826-I 847; funeral invitations, I 844 - I 879 ; papers concerning estates administered by Sykes; surveys, deeds, field notes and related papers created or acquired as a surveyor and conveyancer in Burlington and adjacent New Jersey counties; notes and correspondence, I 840 O-I 870 , concerning local history and genealogy; and miscellaneous other papers. Also tax lists, ca. I800-I 8 IO, and school committee records, I 834-1843, of Springfield Township, Burlington County. 


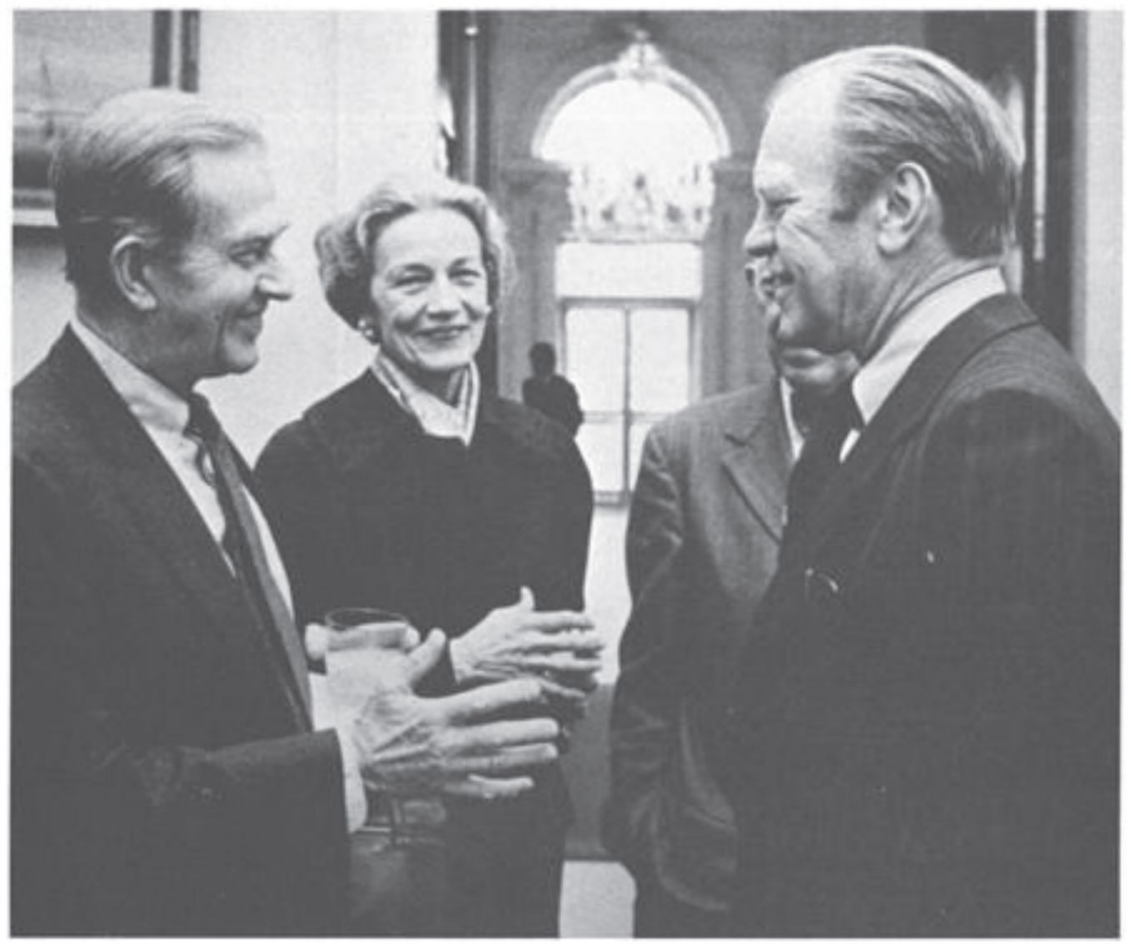

Senator Clifford P. Case and Representatives Millicent Fenwick and Edwin B. Forsythe conversing with President Gerald R. Ford, March I 8, I 976 . In I 983 Ford held the inaugural Clifford P. Case Professorship in Public Affairs at Rutgers University. The Congressional papers of Case, Fenwick and Bell are included among the collections of political papers in Special Collections and Archives.

VROOM, PETER D., I 79I-I 873.

Papers, I 726-I 887.

I. 6 cubic ft.

Member, New Jersey Assembly, I 826-I 827, I 829; New Jersey Governor, I 829-I 832, I 833-I 836; U.S. Representative, I 839-I 84I. Democrat.

Correspondence, I 799-I 873, consisting chiefly of letters received; legal notebook, I 8 I ; legal documents concerning cases handled by Vroom; 
financial documents; scrapbooks, I 856-I 857 , kept while serving as U.S. Minister to Prussia; and miscellaneous other papers, some with no apparent connection to Vroom. Also papers, I 726-I 887, of other family members, including father Peter D. Vroom, Sr. ( I 746-I 83 I).

An additional .35 cubic feet of Peter D. Vroom papers, held as part of the repository's Charles A. Philhower Collection, include correspondence, ca. I 82 I-I 873; legal documents; financial documents, including an account book, I 832-I840; and papers, I 77I-I920, of Peter D. Vroom, $\mathrm{Sr}$., and other family members, including genealogical notes and compilations.

Other papers held by the repository which may share a common provenance with the Peter D. Vroom papers include a portion of the Hunterdon County Miscellany Collection.

Selected letters of Peter D. Vroom (1791-1873) indexed in the repository.

WALL, GARRET D., I 783 -I 850.

Papers, I785-I 867 .

.8 cubic ft.

Member New Jersey Assembly, I 822, I 827 ; New Jersey Governorelect I 829 (declined to serve); U.S. Senator, I 835-I 84I. Father-in-law of Peter D. Vroom. Democrat.

Letters received, I 799-I 850 ; legal documents, I 805 -I 850 , pertaining to cases handled by Wall; financial documents, including vouchers, I 8 I6I 8 I9, as treasurer of the Trenton Township Committee; and papers, I 8 I I-I 835 , concerning estates administered by Wall. Also letters received, I $847-1867$, by son James W. Wall (I820-I872); and miscellaneous papers, I 785-I 86 I, lacking an obvious Wall family connection.

An additional . 2 cubic feet of Garret D. Wall papers, held as part of the repository's Charles A. Philhower Collection, include letters received, I 808-I 849; legal documents; receipts; and letters received, I 863-I 867, by son James W. Wall.

Other papers held by the repository which may share a common provenance with the Garret D. Wall papers include the Charles Coxe papers, I 797-I 83 I , and a portion of the Hunterdon County Miscellany Collection.

Selected letters of Garret D. Wall indexed in the repository. 
WARD, MARCUS L., I 8 I 2-I 884.

Papers, ca. I $782-1884$.

2.4 cubic ft.

Governor of New Jersey, I 866-I 869; U.S. Representative, I 873I 875. Republican.

Correspondence, I 866-I 868, as New Jersey Governor; legal documents and case files, ca. I 782 - I 862 ; veterans' affairs files, I $850-$ I 883 , relating to Ward's philanthropic activities on behalf of Civil War soldiers and their families; personal correspondence, I 83 I-I 884; and newspaper clippings.

WILLIAMS, HARRISON A., JR., I 9 I 9 -

Congressional papers, I954-I982.

ca. 1995 cubic $\mathrm{ft}$.

U.S. Representative, I953-1957; U.S. Senator, 1959-1982. Democrat.

Legislative files and correspondence; Labor and Human Services Committee files; sponsored and co-sponsored bills; voting record; special projects files and correspondence; case files; guest registers; speeches and statements; constituent newsletters; photographs; press releases; press clippings; and other papers.

Access restricted. 